\title{
УДК 656.1
}

DOI: https://doi.org/10.32840/1814-1161/2021-2-9

Ложачевська О.М. доктор економічних наук, професор

Національного транспортного університету

Команчук С.B. аспірант

Національного транспортного університету

Lozhachevska Olena

Doctor of Economics Sciences, Professor, National Transport University

Komanchuk Serhii

Postgraduate Student

National Transport University

\section{РОЗВИТОК ГРОМАДСЬКОГО ТРАНСПОРТУ ШЛЯХОМ УПРОВАДЖЕННЯ ЕЛЕКТРОБУСІВ}

\section{DEVELOPMENT OF PUBLIC TRANSPORT THROUGH THE INTRODUCTION OF ELECTRIC BUSES}

У роботі розглянуто підходи до вибору концепції розвитку нерейкового громадського транспорту на основі автобусних та тролейбусних систем для збалансованого розвитку пасажирських перевезень. Розвиток громадського транспорту в напрямі зменшення негативного екологічного впливу на міське середовище розглядається не лише як бажаний, а й як обов'язковий, але час для повної реалізації переходу на нульовий екологічний вплив невизначений. Цей перехід необхідний не лише для створення більш безпечних екологічних умов у містах, а й для збільшення економічної ефективності, які несуть із собою нові технології. Незважаючи на значні інвестиційні затрати, які можуть виникнути під час упровадження, ці технології здатні призвести до відчутного позитивного економічного ефекту в перспективі. Автори статті розглянули та підкреслили проблеми та особливості, які характеризують кожну концепцію електробусів, та розробили власні рекомендації.

Ключові слова: екологія, електробус, громадський транспорт, міське середовище, транспортна інфраструктура.

В работе рассмотрены подходы к выбору концепции развития нерельсового общественного транспорта на основе автобусных и троллейбусных систем для сбалансированного развития пассажирских перевозок. Развитие общественного транспорта в направлении уменьшения негативного экологического воздействия на городскую среду рассматривается не только как желаемый, но и как обязательный, но время для полной реализации перехода на нулевой экологическое воздействие не является определённым. Этот переход необходим не только для создания более безопасных экологических условий в городах, но и для увеличения экономической эфффективности, которые несут с собой новые технологии. Несмотря на значительные инвестиционные затраты, которые могут возникнуть при внедрении, эти технологии способны привести к ощутимому положительному экономическому эфффекту в перспективе. Авторы статьи рассмотрели и подчеркнули проблемы и особенности, характеризующие каждую концепцию электробусов, и разработали собственные рекомендации.

Ключевые слова: экология, электробус, общественный транспорт, городская среда, транспортная инфраструктура.

The work considers approaches to choosing the concept of non-rail transport development based on bus and trolleybus systems for the balanced development of passenger traffic. The development of public transport in the direction of reducing the negative environmental impact on the urban environment is considered not only desirable and also required, but the time for the full implementation of the transition to zero environmental impact is not defined. This transition is necessary not only to creating safer environmental conditions in cities, but also to increase the economic efficiency that new technologies bring. There is a need not just to introduce higher environmental standards for rolling stock and internal combustion engines, but to find a quality replacement and revise the concept. The city must strive for environmental standards and new technological innovations. These standards will change urban public transport for the better. All over the world, the main trend is the transition to renewable 
energy sources and the introduction of environmental technologies in all areas of human activity. Reducing the number of vehicles with internal combustion engines and the number of harmful emissions with them is a top priority. Emission reductions are achieved through the introduction of new environmental standards and technologies in the automotive industry. Reducing the number of internal combustion engines involves the release of new rolling stock in their place, environmentally friendly. People need to move goods, provide services or meet their own needs. To do this, they often have to use public transport, which is represented by such types as: bus, taxi and trolleybus. Bus public transport is a major polluter of the urban environment. Despite the significant investment costs that may arise during implementation, these technologies can lead to a significant positive economic effect in the perspective. The authors of the article considered the economic component of the issue and highlighted the problems and features that characterize each concept of electric buses, and developed their own recommendations.

Keywords: ecology, electric bus, public transport, urban environment, transport infrastructure.

Постановка проблеми у загальному вигляді та її зв'язок із важливими науковими чи практичними завданнями. Сьогодні чітко стоїть проблема практичної реалізації екологічних заходів у сфері громадського транспорту. Основними трендами розвитку нерейкового громадського транспорту є збільшення його екологічності та економічної ефективності. Передусім йдеться про автобусний громадський транспорт як головний забрудник міського середовища. Постає необхідність не просто впровадження вищих екологічних стандартів до рухомого складу та двигунів внутрішнього згорання (ДВЗ), а й пошуку якісної заміни та перегляду концепції. Нові технології та можливості, які виникли за останні 10 років, мають переваги та недоліки, і залежно від наявних транспортних комунікацій у конкретному місті можливе застосування нових технологій із різною прогнозованою ефективністю. Усе це потребує певних узгоджень, чим характеризується актуальність загальної проблеми.

Аналіз останніх досліджень і публікацій, в яких започатковано розв'язання даної проблеми і на які спирається автор. Значний внесок у розроблення методологічних основ та дослідження перспектив розвитку нерейкового наземного громадського транспорту зробили провідні вчені: М.М. Фарберов, В.Б. Альгін, С.Н. Поддубко та ін. Але поза їхньою увагою залишаються питання ефективної адаптації нових технологій $з$ існуючою електроінфраструктурою міст, а також формування критеріїв, за якими необхідно здійснювати прийняття рішення щодо зміни чи впровадження технологічних нововведень.

Формулювання цілей статті (постановка завдання). Метою даної роботи є аналіз наявних екологічно чистих концепцій електробусів та прийняття рішення щодо вибору концепції на основі енергоефективності.

Виклад основного матеріалу дослідження 3 повним обґрунтуванням отриманих наукових результатів. Сучасне місто повинно прагнути до екологічних стандартів та нових технологічних упроваджень, які змінюватимуть міське життя на краще. У всьому світі найголовнішим трендом останніх десятиліть, а особливо останнього, став перехід до відновлювальних джерел енергії та впровадження екологічних технологій у всіх сфрерах діяльності людини, де це можливо. Одним із таких напрямів $є$ зменшення кількості транспортних засобів із ДВЗ та кількості шкідливих викидів із ними. Зменшення кількості викидів досягається впровадженням нових екологічних стандартів та технологій в автобудівництві. Зменшення кількості ДВЗ передбачає собою випуск рухомого складу на відновлювальних джерелах енергії. Людям постійно потрібно переміщати товари, здійснювати послуги або задовольняти власні потреби і для цього їм часто доводиться користуватися нерейковим громадським транспортом, який представлений такими видами, як автобус, маршрутне таксі та тролейбус.

Недоліки перших двох полягають у великих викидах шкідливих речовин у навколишнє середовище, великому рівні шуму, високих витратах на утримання та ремонт, низьких показниках руху «розгін - стоп» порівняно з тим самим тролейбусом. Якщо автобус може перевозити в середньому близько 100 людей, то маршрутні таксі здатні брати в два-три рази менше. Зі збільшенням кількості маршруток ми отримуємо більше завантаження доріг, більше шкідливих викидів і не набагато більший обсяг перевезень пасажирів. Основними недоліками тролейбуса $є$ його залежність від контактної лінії, неможливість подолати відрізок маршруту у разі поломки контактної лінії або тягової підстанції, неможливість оминути учасників ДТП на дорозі, неможливість оминути затор. I хоча останні роки почали випускати тролейбуси з можливістю автономно подолати кілька кілометрів, але їх швидкість (5км/год.) та інші обмеження є незадовільними.

Таким чином, відчувається необхідність у наявності транспорту, який би мав переваги наявного нерейкового громадського транспорту та водночас був позбавлений недоліків. Таким транспортом може стати електробус як нова ланка еволюції громадського транспорту. Сьогодні існують три основні концепції електробусів.

Електробус із зарядкою в депо - концепція ONC. Основна суть цієї технології в тому, що електробус накопичує енергію під час нічних зарядок у депо, а протягом дня на цьому заряді здійснює перевезення (з можливістю додаткового заряджання протягом дня). Ця технологія вимагає особливого втручання в міську енергомережу. Ураховуючи існуючі технічні обмеження і запас дальності пробігу з коефіцієнтом 1:1 для звичайних дизельних автобусів (12 метрів), довжина пробігу між сеансами підзарядки тривалістю в кілька годин може становити 150 км, теоретично за оптимальних умов експлуатації - до 250 км [1, с. 157]. Однак побічні витрати (опалення, кондиціонер, система опускання підлоги) істотно обмежують дальність пробігу нинішніх електробусів, особливо при температурі $+5^{\circ} \mathrm{C}$ і нижче. На даний момент для забезпечення вищевказаної дальності пробігу при низьких температурах транспортні засоби слід обладнати неелектричними системами обігріву, які 
зазвичай працюють на дизельному паливі, тобто це вже не $є$ екологічно чистим рішенням. Характерна особливість даної технології полягає у тому, що депо обмежене в кількості електробусів, які може прийняти для підзарядки одночасно. Це призводить до необхідності будівництва великих депо з великими інфраструктурними інвестиціями або організації значної кількості середніх і дрібних депо в межах міста. Велика вага акумуляторних батарей технічно обмежує пасажиромісткість рухомого складу. За висновками експертів, у найближчі роки найбільш реалістичним до ефективного функціонування $\epsilon$ 10-12-метровий електробус системи ONC з пасажиромісткістю 80-100 осіб. Для двосекційних моделей існує обмеження через навантаження та осі від великої ваги акумуляторних батарей. Двосекційні моделі досі використовувалися тільки в Китаї і мають дуже короткий діапазон руху - максимум 60 км [2, с. 1]. Таким чином, ця концепція зарядки може замінити лише невелику частину автобусних маршрутів. Якщо виникне додатковий попит на пасажироперевезення, то дана технологія не зможе в найближчі роки збільшити пасажиромісткість одиниці рухомого складу. Виходячи з усього вищевказаного, цей варіант видається одним із найбільш складних у технічному й економічному контексті (потреба в додатковому просторі, водіях тощо).

Для реалізації даної концепції необхідно виконати деякі вимоги, пов'язані з інфраструктурою в депо. Це стосується таких інфраструктурних заходів:

1) установлення зарядних пунктів в депо;

2) збільшення потужності підключення до електромережі відповідно до необхідної потужності (близько 70 кВт на 1 електробус) з одночасною підзарядкою великої кількості транспортних засобів (наприклад, під час нічного простою). Це має бути відповідно узгоджено з міською електромережею на відповідних потужностях;

3) переобладнання майстерень для специфрічного обслуговування електробусів (обслуговування елементів на даху електробусів, можливо, пантографи, використання спеціального діагностичного обладнання та спеціальних ізоляційних інструментів для електричних транспортних засобів тощо).

Унаслідок вибору даної концепції необхідне збільшення території депо порівняно з автобусними чи тролейбусними депо. Окрім того, слід також відзначити, що електричні автобуси з великими батареями з міркувань пожежної безпеки не повинні розміщуватися так само близько, як дизельні автобуси в блоці, щоб уникнути поширення вогню на інші транспортні засоби у разі пожежі.

Електробус із зарядкою на станціях (ОC) - зарядні станції на проміжних та кінцевих зупинках. На відміну від концепції ONC цей концепт теоретично можливо застосувати для випуску двосекційних електробусів 16-18 м, але тут постають значно більші експлуатаційні витрати. Завдяки підзарядці на зупинках з урахуванням маршрутних та експлуатаційних характеристик електробус технології ОС має менші батареї порівняно з ONC, що, відповідно, позитивно впливає на загальну вагу та пасажиромісткість. Залежно від інфраструктури зарядки діапазон може бути збільшений за бажанням. Слід зазначити, однак, що швидка зарядка з високою потужністю зарядки негативно впливає на термін служби акумуляторних батарей [3, с. 117].

Час простою на кінцевих зупинках, який $є$ проміжком часу між двома поїздками, і він необхідний для перерви водія, використовується для підзарядки акумуляторних батарей. Для процесу зарядки потрібно щонайменше від чотирьох до восьми хвилин залежно від умов використання. Беручи до уваги, що електробус повинен відводити час для підзарядки на проміжних станціях та на кінцевих станціях, на завантажених маршрутах це призводить до потреби в додатковому рухомому складі від 10\% до 20\% порівняно з використанням дизельних автобусів [4. с. 2]. Окрім того, стаціонарна інфраструктура, особливо за розміщення на кінцевих пунктах або між ними, значно знизила б оперативність руху по завантажених лініях. Збільшена частота ходу тягне за собою відповідне коригування кількості доступних станцій для зарядки електробусів на зупинках. За цією концепцією електробуса слід також зазначити, що інфраструктура зарядки вимагає додаткового простору на вулицях міста. Ураховуючи, що міський простір здебільшого обмежений, відповідна інфраструктура зарядки не може бути реалізована всюди. Слід зауважити, що стаціонарна інфраструктура зарядки на зупинках створює суттєву обмеженість гнучкості маршрутів. Для швидкої зарядки індивідуальні зарядні станції повинні забезпечувати від 250 до 450 кВт для забезпечення оптимального часу зарядки залежно від розміру транспортного засобу та акумуляторних батарей [5, с. 17]. Проблема тут полягає у тому, щоб забезпечити необхідну короткочасну потужність у різних частинах міста.

Електробус із динамічною підзарядкою - динамічна підзарядка під час руху (IMC) або тролейбус із великим автономних ходом. Технологія динамічної підзарядки (прямо під час поїздки) від контактної мережі, прокладеної для тролейбусних маршрутів, дасть змогу зменшити розмір батареї в два-три рази відносно електробусів із зарядними станціями в депо (ONC) і з зарядними станціями на зупинках (OC). У ході фрункціонування концепції не виникає надмірного додаткового попиту на транспортні засоби, водіїв чи корегування графріку руху. 3 урахуванням значного терміну експлуатації транспортних засобів (близько 15 років) та інфраструктури для зарядки ця технологія показує велику економічну ефективність, особливо на маршрутах із високою частотою ходу (15-хвилинний інтервал або частіше) і напрямках, що включають у себе кілька маршрутів. Окрім того, використовуючи технологію прямої подачі енергії, можна уникнути істотних втрат під час ії̈ трансформації (табл. 1). Отже, динамічна підзарядка показує найбільш високу енергоефективність серед електробусів.

Ця фрорма підзарядки в русі вже використовується сьогодні з дуже високою надійністю в тролейбусних системах у деяких містах Європи. У результаті безперервної підзарядки і подачі струму від контактної лінії на електропривід на значній ділянці маршруту транспортні засоби вимагають лише відносно невеликих запасів енергії та розмірів акумуляторних ба- 
Енергоефективність первинної енергії доступних альтернативних приводів або енергії [7, с. 2]

\begin{tabular}{|c|c|c|}
\hline Енергія приводу & Примітки & Первинна енергетична ефективність \\
\hline \multirow{3}{*}{ Електропривід } & Тролейбус & $74,7 \%$ \\
\cline { 2 - 3 } & Тролейбус 3 ВАХ - IMC & $71,0 \%$ \\
\cline { 2 - 3 } & Електробус - ОNC & $69,4 \%$ \\
\cline { 2 - 3 } & Електробус - OC & $65,1 \%$ \\
\hline Водень & & $28,3 \%$ \\
\hline Газ чи рідке паливо & & $22,8 \%$ \\
\hline
\end{tabular}

Порівняння існуючих концепцій електробусів

\begin{tabular}{|c|c|c|c|c|}
\hline & $\begin{array}{c}\text { Електробус } \\
\text { з зарядкою } \\
\text { в депо - ONC } \\
\text { (Overnight charging) }\end{array}$ & $\begin{array}{c}\text { Електробус } \\
\text { з зарядкою } \\
\text { на станціях - OC } \\
\text { (Opportunity } \\
\text { charging) }\end{array}$ & $\begin{array}{c}\text { Електробус } \\
3 \text { зарядкою } \\
\text { під час руху - IMC } \\
\text { (In-motion charging) }\end{array}$ & Тролейбус \\
\hline $\begin{array}{c}\text { Спосіб накопичення } \\
\text { енергії }\end{array}$ & $\begin{array}{c}\text { Повільна } \\
\text { нічна зарядка }\end{array}$ & $\begin{array}{c}\text { Дуже швидка } \\
\text { зарядка на зупинках }\end{array}$ & $\begin{array}{c}\text { Динамічна зарядка } \\
\text { під час руху } \\
\text { під контактною лінією }\end{array}$ & $\begin{array}{c}\text { Безпосередньо } \\
\text { від контактної лінії }\end{array}$ \\
\hline $\begin{array}{c}\text { Запас автономного } \\
\text { ходу }\end{array}$ & Від 150 км & 20-70 км & 5-70 км & До 5 км \\
\hline $\begin{array}{c}\text { Вимоги } \\
\text { до інфраструктури }\end{array}$ & $\begin{array}{c}\text { Вимагає загального } \\
\text { перегляду } \\
\text { енергосистеми міста, } \\
\text { підведення потужних } \\
\text { енерголіній до депо }\end{array}$ & $\begin{array}{c}\text { Вимагає організації } \\
\text { підзарядних станцій } \\
\text { на зупинках, } \\
\text { прокладення до них } \\
\text { енерголіній }\end{array}$ & $\begin{array}{c}\text { Використовується } \\
\text { існуюча } \\
\text { інфраструктура; } \\
\text { за прокладання } \\
\text { нових маршрутів } \\
\text { у нові райони } \\
\text { контактну лінію } \\
\text { можна не розвивати }\end{array}$ & $\begin{array}{c}\text { Використовується } \\
\text { існуюча } \\
\text { інфраструктура; } \\
\text { за прокладання } \\
\text { нових маршрутів у } \\
\text { нові райони необхідні } \\
\text { капітальні інвестиції } \\
\text { в контактну мережу } \\
\text { і тягові підстанції }\end{array}$ \\
\hline Особливості заряду & $\begin{array}{c}\text { Вимагає } \\
\text { концентрації великих } \\
\text { енергетичних } \\
\text { потужностей у депо }\end{array}$ & $\begin{array}{c}\text { Вимагає заряд } \\
\text { струму понад 300А; } \\
\text { на місцях зарядки } \\
\text { створює різкі } \\
\text { навантаження на } \\
\text { енергосистему }\end{array}$ & $\begin{array}{r}\text { Навантаження н } \\
\text { міста розподіляєть } \\
\text { дня; контактна мер } \\
\text { підстанціями, може } \\
\text { енергопостачання за } \\
\text { пере }\end{array}$ & $\begin{array}{l}\text { а енергосистему } \\
\text { ся протягом усього } \\
\text { ежа, яка пов'язана } \\
\text { забезпечувати стійке } \\
\text { різних перемикань чи } \\
\text { боїв }\end{array}$ \\
\hline $\begin{array}{l}\text { Простій РС } \\
\text { під зарядкою }\end{array}$ & 4-10 годин в депо & 1-25 хв на зупинці & Відс & утній \\
\hline $\begin{array}{l}\text { Акумуляторні } \\
\text { батареї(АБ) }\end{array}$ & $\begin{array}{c}\text { Великий розмір і вага } \\
\text { АБ }\end{array}$ & \multicolumn{2}{|c|}{ АБ середнього розміру } & $\begin{array}{l}\text { АБ незначного } \\
\text { розміру }\end{array}$ \\
\hline $\begin{array}{l}\text { Довговічність } \\
\text { батарей }\end{array}$ & $\begin{array}{c}\text { Глибокий ступінь } \\
\text { розрядки }\end{array}$ & $\begin{array}{c}\text { Високий струм } \\
\text { зарядки і глибокий } \\
\text { ступінь розрядки }\end{array}$ & \multicolumn{2}{|c|}{$\begin{array}{c}\text { 90-240 осіб ( можуть бути як одно-, так і } \\
\text { двосекційні) }\end{array}$} \\
\hline Обігрівання салону & \multicolumn{2}{|c|}{$\begin{array}{c}\text { Для обігрівання салону, АБ і для економії } \\
\text { заряду може використовуватися дизельний } \\
\text { генератор }\end{array}$} & \multicolumn{2}{|c|}{ Електрообігрівання салону } \\
\hline Гнучкість маршруту & $\begin{array}{l}\text { Гнучкий, } \\
\text { як у автобусів }\end{array}$ & $\begin{array}{c}\text { Залежність } \\
\text { від зарядних станцій }\end{array}$ & $\begin{array}{l}\text { Деяка залежність } \\
\text { від контактної лінії }\end{array}$ & $\begin{array}{l}\text { Повна залежність } \\
\text { від контактної лінії }\end{array}$ \\
\hline $\begin{array}{c}\text { Габаритно- } \\
\text { технологічні } \\
\text { обмеження } \\
\text { (довжина РС) }\end{array}$ & \multicolumn{2}{|c|}{ До 12 м } & \multicolumn{2}{|c|}{ До 24 м } \\
\hline Пасажиромісткість & \multicolumn{2}{|c|}{ 80-120 осіб (односекційні) } & \multicolumn{2}{|c|}{$\begin{array}{c}\text { 90-240 осіб (можуть бути як одно-, } \\
\text { так і двосекційні) }\end{array}$} \\
\hline $\begin{array}{c}\text { Кількість РС, } \\
\text { які одночасно } \\
\text { можуть заряджатися }\end{array}$ & $\begin{array}{c}\text { Залежить } \\
\text { від інфраструктури }\end{array}$ & $\begin{array}{c}\text { Одна станція - } \\
\text { один електробус }\end{array}$ & \multicolumn{2}{|c|}{$\begin{array}{l}\text { Залежить потужності електропідстанції } \\
\text { (на практиці це не менше п'яти одиниць } \\
\text { рухомого складу на певній ділянці руху) }\end{array}$} \\
\hline
\end{tabular}


тарей для виконання необхідного маршруту [8, с. 32]. Це безпосередньо приносить користь для ваги електробусу, і, таким чином, збільшується можлива пасажиромісткість. Більш низька вага акумуляторних батарей, відносна економія заряду й ефективне енергопостачання (принаймні половина всієї енергії подається безпосередньо від контактної мережі без проміжних утрат) також забезпечують низьке питоме споживання енергії.

Із цією концепцією руху та заряджання описані вище конфліктні точки з урахуванням енергетичних потреб вторинних енерговитрат рухомого складу (обігрів, кондиціонер тощо) не настільки значні, оскільки додаткову необхідну енергію можна отримати частково безпосередньо від контактних ліній. Регулярно підзаряджаючи батареї під час руху, електробуси IMC мають практично необмежений діапазон руху. Ця концепція не призводить до негайного додаткового попиту на транспортні засоби. Окрім того, технологія може застосовуватися до всіх розмірів транспортних засобів, включаючи 24-метрові великої місткості.

Ця концепція вимагає контактних ліній на певних ділянках маршруту для зарядки акумуляторних батарей, а також енергетичних підстанцій для подачі енергії по контактній мережі. За допомогою табл. 2 можемо порівняти цю концепцію з концепцією ОС, де може заряджатися тільки один електробус, кілька електробусів IMC можуть бути під лінією й одночасно заряджатися. Кількість необхідної інфраструктури залежить від енергомережі. Для експлуатації маршруту, як правило, не менше $50 \%$ маршруту повинно бути обладнано контактною мережею. Оптимізуючи розподіл контактних ліній, можна зменшити частку ліній для всієї мережі міста. Таким чином, кілька ліній можуть бути частково забезпечені і перекриватися на окремих ділянках. Порівняно зі звичайними тролейбусними системами можна обійтися без дорогого, витратного і неестетичного елемента контактної мережі, зокрема на перехрестях. Перезаряджаючи батареї під час руху, електричні навантаження розподіляються просторово і в часі, зменшуючи тим самим вимоги до потужності для нічного заряджання в депо. Термін служби інфраструктури становить не менше 30 років.

Використання електричних систем може призвести до суттєво більших інвестиційних витрат порівняно з аналогічними дизельними транспортними засобами. Залежно від виробника транспортного засобу та конфрігурації транспортного засобу вартість інфраструктури депо та рухомого складу може від 2 до 2,5 разів перевищити відповідні дизельні. Ці додаткові витрати переважно базуються на витратах на розроблення нових транспортних засобів та високих витратах на акумуляторні батареї. Хоча електробуси мають менші витрати через їх низьке енергоспоживання та витрати на обслуговування, порівняно 3 дизельними автобусами слід очікувати саме на значні додаткові витрати, пов'язані з переходом на електричні транспортні засоби. Навіть електробуси з динамічною підзарядкою мають значні інвестиційні витрати. Проте через меншу частку механічно завантажених компонентів з урахуванням практичного до- свіду в експлуатації (транспортні засоби з терміном служби більше 15 років) для концепції IMC можна очікувати більш тривалого терміну служби (дизельні автобуси мають у середньому термін служби 10 років). Відповідно, високі інвестиційні витрати вирівнюються протягом тривалого періоду амортизації транспортних засобів. Підвищений попит на транспортні засоби, що переходять із дизельних автобусів до електричних автобусів нижчої пасажиромісткості, також має значний вплив на економіку системи. Розширення парку рухомого складу тягне за собою збільшення інвестицій у транспортні засоби та інфраструктуру, а також поточні експлуатаційні витрати.

Висновки з цього дослідження і перспективи подальших розвідок. Таким чином, проаналізувавши наявні енергоефективні та екологічні концепції електробусів, можна виділити основні переваги та недоліки кожної з них. У статті розглянуто проблеми енергоефективності запропонованих концепцій та значних інвестиційних витрат. Для ефективного розвитку нерейкового громадського транспорту запропоновано використовувати наявну інфрраструктуру тролейбусів у тих містах, де вона існує, з вибором концепції електробусів IMC. За відсутності відповідної інфраструктури автори рекомендують концепції OC та IMC.

\section{Бібліографічний список:}

1. Гібридні автомобілі : монографрія / О.В. Бажинов та ін. Харків : Крок, 2008. 328 с.

2. Von Christoph Giesen, Max Hägler und Kai Strittmatter, Shenzhen. In der E-Mobilität ist China einen großen Sprung voraus. URL: https://www.sueddeutsche.de/wirtschaft/ autoindustrie-in-der-e-mobilitaet-ist-china-einen-grossensprung-voraus-1.3952643 (дата звернення: 17.09.2020).

3. Синергетичний автомобіль. Теорія і практика : монографія / О.В. Бажинов та ін. Харків : ХНАДУ, 2011. 236 с.

4. Економічні та фрінансові публікації. The Economist. The growth of lithium-ion battery power. URL: https://www.economist.com/briefing/2017/08/12/ after-electric-cars-what-more-will-it-take-for-batteries-tochange-the-face-of-energy (дата звернення: 17.01.2020).

5. Jürgen Brauer. Herausforderungen beim Betrieb mit elektrisch betriebenen Bussen. Leipzig, 2017. P. 30.

6. Akayed Toha Hossain. Bloomberg. New Energy Finance, Electric Buses in Cities, Driving towards cleaner air and lower $\mathrm{CO}_{2}$. 2018. P. 29.

7. Karlsruher Institut für Technologie, Power-to-Gas mit hohem Wirkungsgrad, 2018. URL: https://www.kit.edu/kit/ pi_2018_009_power-to-gas-mit-hohem-wirkungsgrad.php (дата звернення: 07.07.2020).

8. Thoralf Knote, Beate Haufe, Lars Saroch. Ansätze zur Standardisierung und Zielkosten für Elektrobusse. Dresden, 2017. P. 55.

9. Альгин В.Б. Ресурсная механика трансмиссий мобильных машин. Минск, 2019. С. 550.

\section{References:}

1. Bazhynov O.V. (2008). Ghibrydni avtomobili: monoghrafija [Hybrid cars: a monograph]. Kharkiv: Krok, $328 \mathrm{p}$.

2. Von Christoph Giesen, Max Hägler und Kai Strittmatter, Shenzhen. In der E-Mobilität ist China einen großen Sprung voraus. URL: https://www.sueddeutsche.de/wirtschaft/ autoindustrie-in-der-e-mobilitaet-ist-china-einen-grossen-sprung-voraus-1.3952643 (application date: 17.09.2020).

3. Bazhynov O.V. (2011). Synerghetychnyj avtomobilj. Teorija i praktyka: monoghrafija [Synergetic car. Theory and practice: a monograph]. Kharkiv: KhNADU, 236 p. 
4. "The Economist». The growth of lithium-ion battery power. URL: https://www.economist.com/briefing/ 2017/08/12/after-electric-cars-what-more-will-it-takefor-batteries-to-change-the-face-of-energy (application date: 17.01 .2020$)$

5. Jürgen Brauer (2017). Challenges when operating electrically powered buses. Leipzig, p. 30

6. Akayed Toha Hossain (2018). Bloomberg. New Energy Finance, Electric Buses in Cities, Driving towards cleaner air and lower $\mathrm{CO}_{2}$, p. 29.
7. Karlsruhe Institute of Technology, Power-to-Gas with high efficiency, 2018. URL: https://www.kit.edu/kit/pi 2018_009_power-to-gas-mit-hohem-wirkungsgrad.ph $\bar{p}$ (application date: 07.07.2020)

8. Thoralf Knote, Beate Haufe, Lars Saroch (2019). Approaches to standardization and target costs for electric buses. Dresden, p. 55.

9. Aljghyn V.B. (2019). Resursnaja mekhanyka transmyssyj mobyljnikh mashyn [Resource mechanics of transmissions of mobile machines]. Mynsk, $550 \mathrm{p}$. 